\title{
Utilizing Whole Exome Sequencing Reveals a Rare Inherited Variant in ABCA3 Gene
}

\author{
Montaha Al-Iede ${ }^{1}$, Mariam Khanfar ${ }^{2}$, Luma Srour $^{1}$, Raja Rabah ${ }^{3}$, Mousa Al-Abbadi $^{1}$, \\ Belal Azab ${ }^{1}$, and Eman Badran ${ }^{1}$ \\ ${ }^{1}$ The University of Jordan \\ ${ }^{2}$ Jordan University of Science and Technology Faculty of Applied Medical Science \\ ${ }^{3}$ University of Michigan Medical Center
}

June 15,2020

\begin{abstract}
Respiratory distress syndrome (RDS) is one of the most common neonatal diseases causing early life morbidity and mortality. We present a case of a full-term baby born to consanguineous parents who died due to severe progressive respiratory failure (PRF). Whole exome sequencing (WES) identified a homozygous disease-causing variant in the ABCA3 gene. Histopathological and electron microscopic examination of postmortem lung tissue revealed characteristic findings consistent with congenital surfactant deficiency along with the ultrastructural evidence of 'fried-egg' like inclusions. Our study provides thorough clinical, radiological, and ultrastructural analysis of the variant's clinical impact and elucidates WES's valuable role in the molecular diagnosis of (PRF).
\end{abstract}

\section{Utilizing Whole Exome Sequencing Reveals a Rare Inherited Variant in $A B C A 3$ Gene}

Montaha Al-Iede, Mariam Khanfar, Luma Srour, Raja Rabah, Mousa Al-Abbadi, Belal Azab, Eman Badran*

Montaha Al-Iede, MD

Department of Pediatrics, Respiratory section, School of Medicine, University of Jordan, PO Box 13617, Queen Rania St., Amman, 11942, Jordan. Phone: 00962725096

Email: M.al-iede@ju.edu.jo

Mariam Khanfar, MSc

Department of Medical Laboratory Sciences, Jordan University of Science and Technology.

PO Box 3030, Irbid 22110, Jordan.

Luma Srour, MSc

Department of Pathology, Microbiology and Forensic Medicine, School of Medicine, University of Jordan, PO Box 13617, Queen Rania St., Amman, 11942, Jordan.

Raja Rabah, MD

Pediatric and Perinatal Pathology, University of Michigan Health System. CS Mott and VonVoigtlander Women's Hospitals.

Mousa Al-Abbadi, MD 
Department of Pathology, Microbiology and Forensic Medicine, School of Medicine, University of Jordan, PO Box 13617, Queen Rania St., Amman, 11942, Jordan.

Belal Azab, PhD

Department of Pathology, Microbiology and Forensic Medicine, School of Medicine, University of Jordan, PO Box 13617, Queen Rania St., Amman, 11942, Jordan.

Prevention Genetics, 3800 S Business Park Ave, Marshfield, WI 54449, United States

Eman F. Badran, MD. MRCPCH (corresponding author)

Department of Pediatrics, Neonatal-Perinatal division, School of Medicine, University of Jordan, PO Box 13617, Queen Rania St., Amman, 11942, Jordan. Email: emanfbadran@gmail.com Phone +962795608288

Keywords : ABCA3, surfactant, progressive respiratory failure, respiratory distress syndromeFund:

No fund was obtained.

\section{Hosted file}

Abstract.docx available at https://authorea.com/users/333664/articles/459794-utilizing-wholeexome-sequencing-reveals-a-rare-inherited-variant-in-abca3-gene

\section{Hosted file}

Manuscript .docx available at https://authorea.com/users/333664/articles/459794-utilizingwhole-exome-sequencing-reveals-a-rare-inherited-variant-in-abca3-gene 